Ethiopian Journal of Environmental Studies \& Management 8(1): 107 - 112, 2015.

ISSN:1998-0507

doi: http://dx.doi.org/10.4314/ejesm.v8i1.10

Submitted: November 24, 2014

Accepted: January 20, 2015

\title{
DETERMINANTS OF ECO ENTREPRENEURIAL INTENTION AMONG STUDENTS: A CASE STUDY OF UNIVERSITY STUDENTS IN ILORIN AND MALETE
}

\author{
ABINA, M.B., ${ }^{2}$ *OYENIRAN, I.W. ${ }^{2}$ and ONIKOSI-ALLIYU, S.O. ${ }^{2}$ \\ ${ }^{1}$ Department of Marketing, Al-Hikmah University, Ilorin \\ ${ }^{2}$ Department of Economics, Al-Hikmah University, Ilorin
}

\begin{abstract}
The study of what determines eco-entrepreneurial intention is still at its nascent stage, especially in the developing countries. This study, therefore, investigated the determinants of eco-entrepreneurial intention among University students in Ilorin and Malete. Descriptive survey research design using structured questionnaires to collect information from target respondents was adopted for the study. The information sourced covered personality, situational characteristics and environmental consciousness of the respondents. The data collected from the survey were analyzed using the regression method. Findings from the study show that attributes such as self-efficacy, environmental concern and perceived support have significant positive effect on entrepreneurial intention among students, while experience and entrepreneurial education do not have significant impact on entrepreneurship intention. Perceived barrier, on the other hand, significantly deter entrepreneurial intention among student. There is, therefore, need for the government at all tiers to organize entrepreneurial improvement programmes which will include self-efficacy intervention capable of enhancing entrepreneurial behaviour, environmental sustainability and infrastructural development.
\end{abstract}

Key Words: Entrepreneur, Intention, Environment, Self-efficacy, Sustainability, Behaviour

\section{Introduction}

One of the major challenges facing the developing nations like Nigeria is the increasing youth unemployment. The turning out of graduates every year from universities without corresponding job creation capacity necessitated the introduction of entrepreneurship education into the curricular of the tertiary institutions in Nigeria. This is because of its importance in self- employment and job creation. However, despite the prominent roles which entrepreneurship education is playing in providing the opportunity for students to gain the knowledge and skills needed for innovations, joblessness among graduates in developing countries that practice entrepreneurship education as a method of entrepreneurship development is on the increase and only a small percentage of these graduates become entrepreneurs after graduation (Hunjraet al., 2011; Brijlal, 2011). This shows that entrepreneurship education is not equivalent to entrepreneurial intention among students.

Eco entrepreneurial intention is the practice of starting new business in response to an identified opportunity to earn a profit and provide minimum negative environmental externality 
(Kotchen, 2009). Entrepreneurial intention represents an important first step to the engagement in entrepreneurial practice. Plehn-Dujowich (2010) opines that the decision to start a business consists of two levels; rational and motivational. The rational level, on the one hand, focuses on objective reasons to adopt the task, including the environmental conditions that reinforce or penalize certain behaviors (Skinner 1987). While the motivational level, on the other hand, refers to subjective reasons that reflect the decision maker's expectations. Thus, an analysis of entrepreneurial behavior must consider the reasons for this decision. They are a necessary, if not sufficient, element to explain the entrepreneurial process (GarcíaVillaverde, Saez-Martínez and BarbaSánchez, 1999).

Earlier studies (Isaak 1999; Schaltegger, 2002; Cohen, 2006) addressing sustainability and entrepreneurship have dealt exclusively with environmentally orientated entrepreneurship, often called 'ecopreneurship', in more detail. These studies have submitted that the major motivation and goal of engaging in ecopreneurship are to earn money through contributing to solving environmental problems. As espoused by Hockerts and Wüstenhagen (2010), economic goals are the ends of the business whereas environmental goals are considered as integrated part of the economic logic of the business. Hence, the organisational challenge of entrepreneurship is to better integrate environmental performance into the economic business logic or to multiply the number of (small) green businesses.

The determinants of entrepreneurial intention have been extensively studied by researchers in economics and management, due to its importance to the development of an economy by way of job creation and wealth creation. However, the study of what determines eco entrepreneurial intention is still at its nascent especially in the developing countries like Nigeria. Eco entrepreneurial quality in prospective entrepreneurs is important to be studied as this can help in the survival as well as succession of the business and environment. This study therefore, investigates the determinants of eco entrepreneurial intention among students aiming to explore the factors that may inform the adoption and practice of environmentally friendly entrepreneurial activities in Nigeria.

\section{Methodology}

\section{Population and Sample}

The population of this study comprises of final year full-time undergraduate students in three universities situated within Ilorin and Malete (University of Ilorin, Kwara State University and Al-Hikmah University). In the University of Ilorin, there are 8 colleges. Kwara state University has 6 colleges, while Al-Hikmah University has 4 colleges. Altogether, there are 18 colleges/ faculties in these universities.

Selection of the sample was done on faculty basis using stratified random sampling method. A department from each of the colleges/faculties in the three universities was randomly selected and from each selected department, 20 students were selected. The total number of samples was then 360 .

Research Instrument, Data Collection and Data Analysis Technique

Structured questionnaires were administered to selected students. Specifically, a self-administered questionnaire was used because it can 
prevent the respondents from being influenced by the researchers. The questionnaire consists of general information about respondents' background and questions relating to attitude, perception and factors affecting ecoentrepreneurship. The respondents were requested to assess each of the scale items on a Likert point scale used for each statement where $1=$ strongly disagree and $5=$ strongly agree. The main purpose and intent behind designing the questionnaire in such a simple way is to make it easy for the selected samples to respond and thereby get a higher response to the questionnaire. The questions were kept brief and simple. Ambiguity and leading questions were avoided.

Of the 360 questionnaires distributed, 344 questionnaires were fully filled in and returned. This represents about 95 percent of the total sample selected for this study. Data collected for the study were presented using descriptive statistical tools such as mean, standard deviation, Cronbach's Alpha reliability test and regression Table 1: Reliability test

\begin{tabular}{lll}
\hline Constructs & No. of item & Cronbach's Alpha result \\
\hline Entrepreneur intention & 3 & 0.783 \\
Entrepreneur experience & 5 & 0.715 \\
Environmental concern & 4 & 0.765 \\
Entrepreneurial self-efficacy & 6 & 0.703 \\
Perceived support & 3 & 0.727 \\
Perceived barrier & 3 & 0.793 \\
Entrepreneurial education & 3 & 0.818 \\
\hline
\end{tabular}

\section{Descriptive Analysis}

The description of score of each of the variable used in this study is shown in table 2. The table shows minimum, maximum, mean and standard deviation for the variables. The results in the table are the summation of all the items belong to each variable from the five-point Likert scale. Mean scores of self-efficacy is 4.036 analysis. Regression analysis was used to examine the factors affecting ecofactors stated in section 2 on ecoentrepreneurial intention was tested based on the estimated coefficients obtained from regression analysis. SPSS 18.0 was used to analyze the collecteddata. The model for this study is stated below as:

Intention $=\mathrm{F}$ (previous experience, environmental concern, self- efficacy, perceived support, entrepreneurial education).

\section{Results and Discussion Reliability Test}

The reliability test results of the seven constructs used in the study are shown in the table 1. All the other constructs have high reliability value as measured by Cronbach's Alpha reliability test. The reliability test of each construct are higher than 0.7 as suggested by Hair et al. (1998). This implies that the items concerned adequately measure a single construct for each tested variable. entrepreneurial behavior. The effect of
$(=24.2174 / 6)$ in a five-point Likert scale. This show the respondents have high positive evaluations of the self-efficacy of eco-entrepreneurial intention as a factor. Based on the average value of environmental concern 3.3096 (13.2384/4), it can be said the respondents had slightly higher environmental concern. However, the average value of entrepreneurship 
education received on environmental sustainability $2.421(7.2656 / 3)$ is slightly low 2.5. This shows that most of the students are not given adequate information on environmental sustainability.

Besides that, the average means score for perceived support is $3.294(=9.8837 / 3)$, for perceived barrier it is 3.1841 $(=9.5523 / 3), \quad$ and for entrepreneurial experience1.6673 $\quad(=8.3367 / 5) . \quad$ These scores mean that students are environmentally concerned, self-confident of their ability to innovate, have intention to innovate, agree that education on ecoinnovation is inadequate, and believe that eco-innovation can be supported and inhibited and had no or little experience of entrepreneurship.

Table 2: Descriptive statistics

\begin{tabular}{lllll}
\hline & Minimum & Maximum & Mean & Std. Deviation \\
\hline Intention & 6.00 & 15.00 & 12.6512 & 2.88059 \\
Experience & 7.00 & 9.00 & 8.3367 & 0.74343 \\
Environmental concern & 7.00 & 28.00 & 13.2384 & 3.58750 \\
Self-efficacy & 13.00 & 29.00 & 24.2174 & 4.03623 \\
Perceived support & 3.00 & 15.00 & 9.8837 & 2.76555 \\
Perceived barrier & 4.00 & 14.00 & 9.5523 & 2.61920 \\
Entrepreneurial education & 4.00 & 18.00 & 8.9186 & 3.11036 \\
\hline
\end{tabular}

\section{Presentation of Regression Result}

The regression result of the factors affecting the eco-entrepreneurship intention is presented below;

Table 3: Regression result

Dependent variables: Intention

\begin{tabular}{lll}
\hline Variable & coefficients & t-statistic \\
\hline Concern & 0.241 & $5.405^{* *}$ \\
Education & -0.036 & -0.563 \\
Self-efficacy & 0.562 & $7.442^{* *}$ \\
Perceived barrier & -0.622 & $-16.746^{* *}$ \\
Perceived support & 0.746 & $6.980^{* *}$ \\
experience & 0.059 & 0.304 \\
R-squared & 0.858 & \\
Adjusted R-squared & 0.853 & \\
F-statistics & $190.126^{* *}$ & \\
** significant at 5 percent &
\end{tabular}

The result shows high degree of goodness of fit. The coefficient of determination is 85 percent and the measure of overall fitness of the model (Fstatistic) is significant at 5 percent. The model result shows that proposed factors (self-efficacy, environmental concern, perceived support, perceived barrier, entrepreneurial education, and experience) have joint significant impact on ecoentrepreneurial intention. Also, these factors explain about 85 percent variation in eco-innovation intention among students. Individually, of the six factors, only four have significant impact on ecoentrepreneurial intention. These are; environmental concern, self-efficacy, perceived support and perceived barrier. 
Both experience and entrepreneurial education are insignificant determinants of eco-entrepreneurial intention. The result shows that self-efficacy, environmental concern, perceived support and experience have a positive impact on ecoentrepreneurial intention, while perceived barrier and entrepreneurship education have a negative effect on eco-entrepreneurial intention.

The six factors put forward are selfefficacy, environmental concern, entrepreneurship education, perceived support, perceived barrier and experience. The study found that attributes such as selfefficacy, environmental concern and perceived support have significant positive effect of entrepreneurial intention among students, while experience and entrepreneurship education do not have significant impact on entrepreneurial intention. Perceived barrier, on the other hand, significantly deter entrepreneurial intention among student.In terms of impact of previous experience in businesses on entrepreneurship, and whether student's parent or relative who own business entity influences their eco-entrepreneurial intention the findings were not statistically significant. Experience was found to be an insignificant factor of eco-entrepreneurial intention. This finding corroborates that of Ismail et al. (2009).

Also, the findings that self-efficacy and environmental concern significantly predicted eco-entrepreneurial intention are consistent with previous studies (Chen et al., 1998, McMullen and Shepard, 2006). The significant relationship between eco entrepreneurial intention, environmental concern, perceived support and selfefficacy specify that absence of these variables can weaken entrepreneurial behaviour among universities students.

\section{Conclusion}

It could be deduced that all the three independent variables have the power of predicting eco-entrepreneurial intention. It, therefore, implies that there is need for the government at all tiers to organize entrepreneurial improvement programmes. Such programmes should include selfefficacy intervention capable of enhancing entrepreneurial behavior, environmental sustainability and infrastructural development programmes.

Moreso, the entrepreneurship education existing in the universities should incorporate element of environmental studies to enhance students' awareness of the need for environmental sustainability and to induce attitude towards ecoentrepreneurship.

\section{References}

Brijlal, P. (2011). Entrepreneurial perceptions knowledge: A survey of final year university students. African Journal of Business Management, 5(3): 818-825.

Chen, C.C., Greene, P.G. and Crick, A. (1998). Does entrepreneurial selfefficacy distinguish entrepreneurs from managers? Journal of Small Business Venturing, 13(4): 295-316.

Cohen, B. (2006), Sustainable valley entrepreneurial ecosystems, Business Strategy and the Environment, 15: 114.

García-Villaverde, P.M., Saez-Martínez, F.J. and Barba-Sánchez, V. (1999). Análisisdel resultado de lasempresas de nuevacreación: influencia de la estrategia y el sector de actividad. Revista Europea de Dirección y Economía de la Empresa, 8: 109-226.

Hockerts, K. and Wüstenhagen, R. (2010), "Greening Goliaths versus emerging 
Davids. Theorizing about the role of incumbents and new entrants in sustainable entrepreneurship", Journal of Business Venturing, in print.

Hunjra, A.I., Ahmad, H.M., Ur-Rehman, K. and Safwan, N. (2011). Factors influencing intention to create new venture among young graduates. African Journal of Business Management Review, 5(1): 121-127.

Isaak, R. (1999). Green logic: Ecopreneurship, theory and ethics. West Hartford: Kumarian.

Isaak, R. (2005). 'The making of the ecopreneur.' In: Schaper, M. (ed.), Making ecopreneurs: Developing sustainable entrepreneurship, Corporate Social Responsibility. London, UK.

Ismail, M., Khalid, S.A., Othman, M., Jusoff, K., Abdul Rahman, N., Mohammed, K.M and Shekh, R.Z. (2009). Entrepreneurial intention among Malaysian undergraduates.
International Journal of Business and Management, 4(10): 54-60.

Kotchen M.J. (2009). Advances in the study of entrepreneurship innovation and economic growth. Emerald Group Publishing Limited.

McClelland, D.C. (1961). The achieving society. Priceton, NJ: Van Nostrans Reinhold.

McMullen, J. and Shepherd, D. (2006). Entrepreneurial action and the role of uncertainty in the theory of the entrepreneur, Academy of Management Review, 31(1): 132-152.

Plehn-Dujowich, J. (2010). A theory of serial entrepreneurship. Small Business Economics, 35: 377-398.

Schaltegger, S. (2002). A Framework for ecopreneurship: Leading pioneers and environmental managers to ecopreneurship, Greener Management International, 38: 45-58.

Skinner, B.F. (1987). Whatever happened to psychology and the science of behaviour. American Psychologist, 780-786. 